\title{
EMPOWERING TO THE STUDENTS ON ENGLISH LITERATURE: PROSE AND POETRY LESSON ON FIFTH SEMESTER IN ENGLISH EDUCATION STUDY PROGRAM THE FACULTY OF TEACHER'S TRAINING AND EDUCATION ASAHAN UNIVERSITY ACADEMIC YEAR OF 2017/2018
}

\author{
Paisal Manurung ${ }^{1}$, Bambang Gulyanto $^{2}$ \\ Lecture of Asahan University, Lecture of DPK in Asahan University \\ paisalmanurung@yahoo.com ${ }^{1}$,Bambanggulyanto36@gmail.com ${ }^{l}$
}

\begin{abstract}
ABTRACK
This research was designed to see the empowering the prose and poetry lesson on the Fifth Semester in English Education Study Program the Faculty of Teacher's Training and Education Asahan University Academic Year of 2017/2018. This research used the qualitative and quantitative approach. Qualitative data was conducted in two cycles (first and second cycles) at the Fifth Semester of English Education Study Program. Each cycle consisted of four steps namely planning, action, observation, and reflection. Then, qualitative data were collected by using observation, questionnaire, interview, field notes, and document. The qualitative data were analyzed by suggested by Burns (1999:175-159) that are assembling data, coding the data, comparing the data, building interpretation, and reporting the outcomes. The quantitative data were analyzed by using descriptive statistics. The research findings and shows that the prose and poetry lesson could empower the English literature in speaking and writing skill. In addition, prose and poetry lesson could be used to improve the class situation. The researcher also found the syllabus of this lesson must be revised each the new academic year.
\end{abstract}

Keywords: empowering, prose and poetry, action research, literature

\section{INTRODUCTION}

Education is defined as a conscious planned action to create learning atmosphere and learning process in which the students develop their potency activity to get religious spiritual competence, self control, character, intelligence, fine moral, and skill needed by themselves, society, country and the nation (Act 20: 2003). Ideally if the education process is correlated by literature basic as the human culture, so the quality of human resources and society will develop significantly into the human correlation perceptively.

However, the social cultural situation could be correlated by the curriculum in the school and university. There are some phenomenon of education today which harassing the students' character. Many embarrassing cases blow up such as adolescence naughtiness, demonstration, degradation of moral value, unfairness action, degradation of solidarity, juvenile delinquency and the rapid development of corruption even within the education and curriculum system itself.

These situations should be reduced by providing character education and the curriculum system. Especially, education and curriculum system in university, it is not seem to be clear in teaching and learning process, so that the student's aimed develops the value of nation character unclear in their activity.

The implementation of value of nation character of education and literary works are not in separate subject. Its meaning that education is not done explicitly rather developed trough the teaching of subjects, such as math, science, and English (Putra at, al, 2014).

Especially for English, the incorporation of character education is highly required. It is because language learning has central role in students' intellectual, social, and emotional development and becomes key element of success in learning other disciplines. Language learning is expected to help learners to understand themselves, their culture and the other culture ( Putra at al, 2014).

In English subject matter, the competencies involved in mastering the four language skills which are listening, speaking, reading, and writing (Utami, at al, 2014). It is expected that the students 
in university grade are able to communicate by using the memorable speech. In the communication situation, they are expected to be able to express information, thought, feelings and also to appreciate culture and develop science and technology (BSNP, 2006).

The appreciation of culture is already being part of the expectation along with other competences. The considerations of involving culture in the educational process are because it contains moral value and close to students' life in the society (Utami, at al, 2014). Based on Etymology Dictionary (Doughlas Herper, 2010), culture is defined as the integrated pattern of human behaviour that includes thought, speech, action, and artefact and depends upon the human capacity for leaning and transmitting knowledge to succeeding generation. Moreover, literature may be defined as the implementation how the process of education could run well. Both aspects in the process of teaching and learning were raised such as language, beliefs, attitudes, ways of behaving, and food preferences Utami at al (2014) cited Slavin, 2009.

Therefore, the research interested to empower better material, especially for Fifth Semester English Education Study Program the Faculty of Teacher's Training and Education Asahan University Academic Year of 2017/2018 by conducting research and development. The research was done at fifth semester because this class has the prose and poetry lesson and the second point that this program is English Education Study Program. A preliminary observation was done to know student's attitude toward the existing literary works. The observation was done through interview toward to head prodi of English Education Study Program. Form the interview, it was found that there are two potentials the students' needed. The first was prose's material could improve their vocabulary which contained many of words to their communication. And the second one was poetry's material could improve the arrangements of their words into the memorable speech. Therefore, this lesson admitted their competence in four skills in English, but also their competences in their activities. Therefore, Weliawati (2014) cited Mayer and Clark (2008) stated that student will have meaningful learning when they appropriately angage in all three important cognitive processes; namely (1) pay attention to relevant words and images in the presented material (selecting words and images), (2) organize the selected material in coherent verbal and pictorial representations (organizing words and images), (3) integrate incoming verbal and pictorial representation with each other and with existing knowledge (integrating).

Meanwhile, the purpose of this research was to empower the student's competences and potentials in the literary works trough the prose and poetry lesson at students of Fifth Semester in English Education Study Program the Faculty of Teacher's Training and Education Asahan University Academis Year of 2017/2018.

\section{OBJECTIVE OF THE RESEARCH}

This research is to identify the some of view:

1. To identify the literature lesson can empower the student's speaking and writing skill in literary works' appreation.

2. To make recommendations to empower the literary works to the another lessons especially in education lesson.

3. To describe the phenomenon of the literature lesson to the students in empowering to speaking and writing skill.

\section{METHODOLOGY OF THE RESEARCH}

This study was classroom action research (CAR). Classroom action research is reflective process which helps teachers to explore and examine aspects of teaching and learning and to take action to change and improve. Classroom action research are provided for teachers who want to understand about teaching and learning, develop teaching skills and knowledge, and take an action to improve students' learning. In the classroom action research, researcher enters the classroom, watches, and records what happen there, and reports his or her finding. Classroom action research is part of action research in which this is a strategy of research that passes the control of practice over the individual teacher in a specific setting. The conventional view of this strategy is that practioner may follow a certain action-reflection procedure that will allow them to improve unsatisfactory situation.

This procedure is one of identification of a problem, and subsequent resolution of the problem through a process of observation-solution- action-reflection-modification.1 As stated by Penny, according to one convention, action research is meant primarily to improve the teacher-researcher's 
own teaching. It based on a cycle of investigation, action, and re-investigation, and is usually done by two or more collaborating teachers. 2 The design of classroom action research used in this study was a cyclical process adapted from spiral model of Lewin which consists of four steps: planning, acting, observing and reflecting.

Actually the first step that would be conducted by the researcher was preliminary study toward the teaching of English of second grade of language class program at Islamic Senior High School Lamongan. It was done to find and identify the class problem. The finding of the preliminary study then analyzed.

Then, the plan was made by the researcher based on the findings in the preliminary study. In the planning step, the researcher design a lesson plan for teaching English, especially for speaking skill (appendix I). It consists of formulated objective, selected and organized materials. The researcher also prepared media and observation checklist. In the planning step, the researcher implemented the plan that had been formulated in the planning stage. In the observing step, the research record the students' conversation and observed the classroom activities then explained the activities that had been done during the observation stages for further planning, acting and soon, for the next cycle.

Then in the next cycle, the researcher made some revisions on the teaching strategy. And this kind of activities would be repeated for several times until expected result was obtained. The detailed model of classroom action research was illustrated as follows:

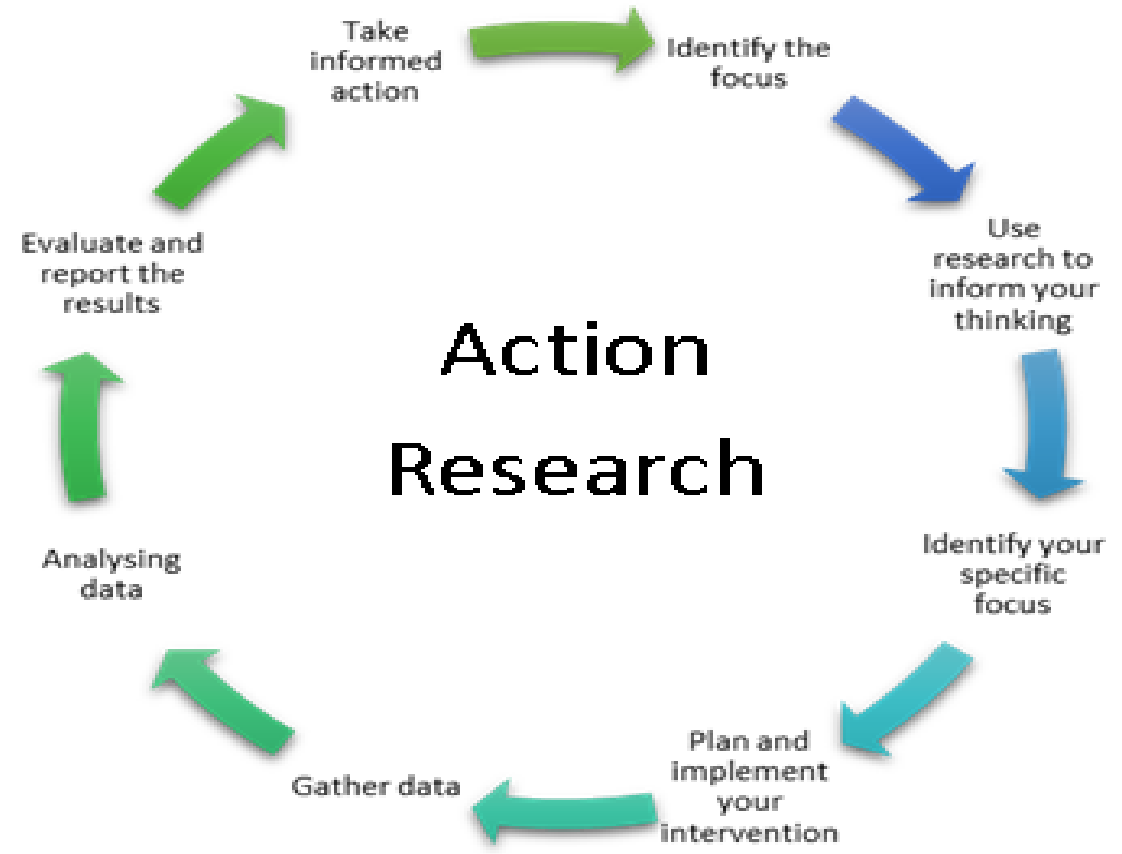

Figure 1

\section{CURRICULUM}

Curriculum is an indispensable part of any formal education, and plays vital part in it. The term curriculum means different things to different people, the following are some opinions regarding the term curriculum Putra (2014). It would be cleared based on the The National Education Standardization Board (BSNP) defines curriculum as a set of plans and arrangements about aim, contents, and subject matter, material and the technique of implementation, which is used as a guideline of education implementation to achieve certain education goals Putra (2014) cites BSNP (2006).

Putra (2014) cited Kwartolo (2002) as cited in Meiyana (2010) defines curriculum as a plan or program for all the experiences which leaner encounters under the direction of the school (organization of institution). Shortly, curriculum can be said that the main arrangements to learn of the program or system affectively consists number of plans in a written form and of varying experiences.

In line the above definition, the Indonesian National Education System Act No. 20 year 2003 defined curriculum as a set of the arrangements and setting about objectives, contents, and sharing 
material, and the means which is used as the guidelines if implementing learning activities in achieving certain objectives.

From the definition of curriculum above, Putra (204) we can further recognize that curriculum is a central education planning which involves the participant of all school components comparing decision makers, and societies including school committee; stake holder; entrepreneurs; and government.

\section{SYLLABUS}

Syllabus is a planning of teaching leaning in a and/or group of subject/theme which includes competence standard, basic competence, learning indicator, learning objective, learning material, time allocation, teaching method, teaching learning activity, teaching evaluation, and learning source (Arrangement Guidance of School Based Curriculum publisher by Educational National Standard Agency Chapter III, Item A) Putra (2014). Therefore, syllabus is a file or document that a teacher or lecture writes or creates to their students with an overview of a course. Normally, it is provided to the class on the first meeting.

\section{LESSON PLAN}

Lesson plan is a plan to picture procedure and organization of teaching to achieve a basic competence (Material of School Based Curriculum Technical Guidelines 2009). Lesson plan is described from syllabus to direct students' learning activities in achievening basic competence (Attachment of Regulation of National Education Minister No. 41 2017, II item B) Putra (2014).

\section{RESEARCH METHODOLOGY}

This research was held from September 2017 to January 2018 at English Education Study Program, The Faculty of Teacher's Training and Education, Asahan University at Fifth Semester. This research was done through lesson of prose and poetry course in the classroom in fourteen meeting. The material of prose and poetry was given on the first and last meeting. There are two kinds of data namely takes: Qualitative and Quantitative data. The qualitative data were collected by using some technique that are interview, observation, and questioner. The quantitative data were collected by using first and second cycles. To know the instruments used in fist and second cycle had collected by using namely:

Cycle I The stages of action of each cycle to be carried out by researchers are as follow :

1. Planning

- Prepare lesson plans.

- Defining collaboration with peers as a research partner.

- Designing observation sheets for students.

- Designing for researcher observation sheet.

- $\quad$ Preparing the student worksheets and answer keys.

- Designing a formative test in literature gendre in speaking and writing.

- $\quad$ Preparing the enquette.

2. Action

- Researchers prepare the necessary props.

- Researchers held a presence on student attendance.

- Researcher explains to students about the patterns of cooperation among students in a group.

- $\quad$ Researchers prepare teaching materials to do the group.

- $\quad$ Researchers provide pre-test to students about the material that will be taught in speaking and writing.

- The researcher briefly explains the new material.

3. Observation

- Observation of the student:

- Supplies of equipment students.

- Attention to the way researchers explain the lesson material.

- Cooperation in the group.

- Facilities and Infrastructure 
- Class a fun situation.

- $\quad$ Structuring student seating.

- The textbooks that support.

- Tools necessary props.

4. Reflection

Reflection is a step to analyze the students' work. The analysis was performed to measure both the strengths and weaknesses contained in Cycle I, then discuss the results of the analysis in collaboration to empower the implementation of Cycle II.

Cycle II

1. Planning

- Identify the problem and formulating the problem based on reflection on the Cycle I.

- Determining back collaboration with peers as partners' research.

- Designing observation sheets for students.

- Designing for researcher observation sheet.

- Designing returning student worksheets in speaking and writing.

2. Action

- Designing formative pre-test in speaking and writing test.

- The researcher prepares the necessary props back.

- The researcher held a presence back on student attendance.

- The researcher held a question and answer that lead to the subject matter.

- $\quad$ Researcher redistributes students with paper test in speaking and writing.

- The researcher can provide assistance on an individual basis if there was a mistake experienced the students.

- The researcher gives a score to the results of a successful to the students seen as less successful in solving task.

- The researcher provides materials briefly before giving assignments

- $\quad$ Researchers conduct small tests based on the fact obtained by the students.

3. Observation

Observation of the student :

- Supplies of equipment students.

- $\quad$ Attention to the researcher explaining the subject matter.

- Facilities and Infrastructure

- Class a fun situation.

- $\quad$ Structuring student seating.

- The textbooks that support.

- $\quad$ Tools necessary props.

4. Reflection

Analyze again to obtain conclusions about the class action that action that has been done. It is expected that by the end of Cycle II, the ability to speak and to write can be empowered thought English literature: prose and poetry.

The data in the study sourced from the interaction of researchers and students in learning and from of action learning of data generated from the act of teaching. Data collecting will be done by; test, and observation sheets.

The data in the first cycle and the second cycle tell that empowering to the students on English Literature: prose and poetry lesson can empower the students' speaking and writing skills because the empowering of the materials give the students opportunity to speak in speaking class with their members group and another group. In the fact, in the first cycle the students cannot be able to reach the criteria of success because they seldom practice speaking in the class due to lack of confidence with their skills. In the second cycle the students speaking skills better than the first cycle and they can use English as a tool of communication and their pronunciation was better.

Empowering to the students on English Literature: prose and poetry lesson is a cooperative learning strategy that is effective in changing the discourse pattern in classroom. These things had been empowered to speak and to write in English literature. It challenges the assumption that all recitations or discussions need to be held in whole group settings, and it has been built in procedures for giving students more time to think, respond, and to help each other. Besides, it encourages individual participation and it is applicable across all grade levels and class sizes in addition to be helpful in organizing students' knowledge and motivating in learning new topics. As one of the cooperating 
learning strategies, empowering to the students on English Literature: prose and poetry lesson encourages the students to work collaboratively faster and more efficiently. Have greater retention and feel more positive about the learning experience.

The result of the research in implementation of using empowering to the students on English Literature: prose and poetry lesson in class indicated that there was an increase in student average scores, in the first test, there were the students averages values about $72,77 \%$ where fifteen students got 75 or more and twenty one students got the score less 75 , in the second tests, there were the students average values about $82,72 \%$ where only six students did not reach the criteria of success, and there were thirty students reached the criteria of success.

The result of the study using empowering to the students on English Literature: prose and poetry lesson showed that the students speaking and writing skills increased. The number of students shared, asked, answer question, and remember some words increased. This occurred since the technique encouraged students to share ideas, asking questions as well as answering questions between groups. Thus, simultaneous interactions between groups and among class were apparent.

The success of the implementation of Empowering to the students on English Literature: prose and poetry lesson that has been proven to improve the students listening and writing as well as enhancing student participation in term of sharing ideas, asking, answering the questions, and making descriptive text was closely related to the role of the researcher. The researcher did not only involve in designing lesson plan, preparing the materials as well as the media but also in developing the procedures of empowering to the students on English Literature: prose and poetry lesson that ultimately resulted in the increase of the student speaking and writing scores and participation. Thus, the researcher role was definitely crucial for the successful implementation of the strategy. It was proven when the researcher developed the empowering to the English Literature: prose and poetry.

\section{FINDING AND DISCUSSION}

This research was conducted through two cycles, each cycle consisted of one session of 90 minutes. The activities of the cycle divided four steps which consisted of planning, implementation, observation, and reflection.

Before the action of cycle II continued, the researcher must know the findings are implemented in the action of cycle I, as a reference on the second cycle. In the action of cycle II, researcher find out that the cycle of action to determine the success of action research.

Furthermore, the result of questionnaire that (1) the students like to study up English literature. (2) Empowering to the students on English Literature: prose and poetry lesson helped students to improve their speaking and writing skills. (3) empowering to the students on English Literature helped the students to share their ideas with other. (4) Empowering to the students on English Literature: prose and poetry lesson helped the students to improve their speaking and writing skills in answering the questions. (5) Empowering to the students on English Literature: prose and poetry lesson helped the students empower their skills in dictate a word. (6) Empowering to the students on English Literature: prose and poetry lesson helped the students improve their pronunciation. (7) Empowering to the students on English Literature: prose and poetry lesson helped the students increase their self confidence brave to speak up. (8) Empowering to the students on English Literature: prose and poetry lesson needed to be continuously applied in speaking and writing lesson.

In addition, the research finding yielded the final procedures of empowering to the students on English Literature: prose and poetry lesson in teaching speaking and writing which divided into three phases. The first phase was pre-activity; (1) the researcher conveys the material of using prose text in writing skill to the students and poetry text in speaking skill competence that wants reached. (2) Asking some oral questions related to the descriptive text. (3) Asking the students to predict what the topic will be discussed. (4) Asking the students to think about the material or problem that is conveyed by the researcher.

The second phase was while-activity; (1) Asking the students about the descriptive text in speaking and writing. (2) The students asked to make a group with their friends (six students) and they explain their thinking result each them. (3) The students asked to dictate to members group. (4) Asked the students to run to their own group and dictate a word. (5) Giving the example about descriptive text. (6) Giving the time to the students for remember a word and sentences to dictate to their members group orally. (7) Explaining the steps and activities the students will be done in the speaking class. (8) Asking the students to answer the complete sentence individually and circulating and providing 
assistance if needed. (9) Assigning the students to sit in group. (10) Asking the group to discuss the answer questions and encouraging the students to help each other, monitoring and providing assistance if necessary. (11) Asking the group to report and write their answer.

The third phase was post-activities; (1) Re-checking the students answer. (2) Writing and speaking down the suitable answers on the board. (3) Making conclusions of the topic and closing the class.

\section{CONCLUSIONS AND SUGGESTIONS}

The conclusions of the data study are :

1. In preliminary study, quantitatively, only fifteen students got a good score and reached the criteria of success. Qualitatively, the students speaking and writing skills in literature text are unsatisfactory, most of the students cannot speak and write English well.

2. In cycle 1 , quantitatively there were only $72,77 \%$ in which 15 students got $\geq 75$ and 21 students got $\leq 75$. This cycle still did not reach the criteria of success yet, in other word, the research was still being continued to the next cycle. Qualitatively, the students speaking and writing skills have empowered, many students' wants to share their ideas and show their performance in acting on the stage.

3. In cycle 2, quantitatively, the students' score in practice speaking and writing as well as the students speaking and writing skills, especially in literary text has empowered. There were $82,72 \%$ in which 30 students got $\geq 75$ and 6 students got $\leq 75$. In this cycle, the criteria of success have already reached or in other word, the research is success and did not need to continue to the next cycle. Qualitatively, most of students were active in the class using empowering to the students on English Literature: prose and poetry lesson in terms of sharing ideas, answering questions, and making a literacy text. In addition, the students' opinion toward the implementation of empowering to the students on English Literature: prose and poetry lesson were positive.

4. By using empowering to the students on English Literature: prose and poetry lesson especially on speaking and writing in the fifth semester the English Education Study Program the Faculty of Teachers" Training and Education can be empowering.

There are some suggestions to offer to the English researchers and the students based on the research findings and discussion. Based on the advantages of using the empowering to the students on English Literature: prose and poetry lesson to the fifth semester in English Education Study Program, the researcher would like to give some suggestions to be considered by English researchers and students as follows :

1. The empowering to the students on English Literature: prose and poetry lesson is the good used in training the students thought as well. Thereafter, the empowering to the students on English Literature: prose and poetry lesson emphasize on increasing of the power of students mind, the power of the students critical, the power of students imagination and the power of analysis toward the literature aspects. Based on the effectiveness the implementation of the empowering to the students on English Literature: prose and poetry lesson in the speaking and writing's empowering students learning motivation, particularly in sharing ideas, answer question, and making a literary text and also can be complete sentences, it is suggested that the English researcher implement the strategy as an alternative strategy in English instruction in addition to other strategies and create the student-center instruction.

2. The empowering to the students on English Literature: prose and poetry lesson empowering the cooperative between the student because they are formed in group, it in increases the students' skills convey the opinion as implementation of the knowledge, and it increase the students' skills in speaking and writing were appreciated the other opinion. Not only that, it can increases the power of students mind, the power of students critical, the power of students imagination and the power of analysis toward the problem. And it recommended that the students employ empowering to the students on English Literature: prose and poetry lesson as a learning strategy to practice their speaking and writing.

3. To motivate students' learning activeness need for an appropriate learning strategies, so that the process of teaching and learning activities to be more variations and no monotonous. 
4. The researcher more enables to enhance the children knowledge when finished the discussion. And it can be used by other researchers to explore more about strategy to empower the students' speaking and writing skills.

\section{REFERENCES}

Broughton, Geoffrey. 1980. English Teaching English as a foreign Language. New York: Routledge. Broom, Martin. 2000. Teaching and Researching Speaking. London. Longman.

BSNP. 2006. Standard Kompetensi dan Kompetensi Dasar SMK/MAK. Jakarta: Badan Standard Nasional Pendidikan.

Burkart, Grace Stovall.2008. Spoken language: What it is and how to teach it. http://www.nclrc.org/speaking.htm. Accessed on October 17th 2014.

Finnie, Sue. 2000. English Practise and Progress. New York: Scholastics.

Harmer, Jeremy. 2003. The Practise of English Language Teaching England: Pearson Education Limited. Teaching. Ediburgh: Pearson Education Limited.
Ten

Heaton, J.B. 1998. Writing English Language Tests. London. Longman Group, Ltd.

Hopkins, D. 2008. A Teacher's Guide to Classroom Research. London: copyright Licensing Agency, Ltd.

Hutchinson, T and Waters, A. 2004. English for Specific Purposes. Chambrige: Chambrige University Press.

Lado, Robert. 2003. Improving Speaking Skill. http://www.selfknowlegde.com. Accessed on October 13th 2014

McNiff, Jean. 1993. Teaching as learning: An Action Research Approach. p.14 2 New York: Mackays of Chatham PLC.

Noparat.2007. Working in Group. www.Philselfsupported.com. Accessed on November 2nd 2014.

N, Namdi, K.A. 2005. Guide to teach Reading. France: Nations Education.

Richard, J.C. et al.2002. Methodology in Language Teaching. New York: Chambrige: Chambrige University Press.

Putra, B.M. et all. 2014. Developing Character Based Lesson Plans For the Tenth Grade Students of Vocational School (SMK). Indonesia: Ganesha University.

Peraturan Menteri Pendidikan Nasional (Permendiknas) Nomor 41 Tahun 2017.

Sigiyono. 2010. Metoda Penelitian Kualitative, Kuantitatif, dan R\&D. Bandung: Alfabeta Bandung.

Undang-Undang Republik Indonesia Nomor 20 Tahun 2003 Tentang Sistem Pendidikan Nasional (UU Sisdiknas).

Utami, Ida A.M.I et all. 2014. Developing Culture Based Supplementary Reading Material Fot The Eight Grade Students of SMP Laboratorium Singaraja. Indonesia: Ganesha University.

Ur, Penny. 1996. A Course In Language Teaching p.328. Cambridge: Cambridge University Press. 